\title{
Thai Consumers' Perception on Herbal Cosmetic Products: A Comparative Study of Thai and Imported Products
}

\author{
Rojanadilok Thanisorn*, Nanagara Byaporn, Bunchapattanasakda Chanchai \\ School of Management, Shinawatra University, Thailand \\ *lovefirstsign@hotmail.com
}

\begin{abstract}
This research investigated the factors that influence perception of Thai consumers on facial herbal cosmetic products in Thailand. In- depth interview the perception of Thai consumers was utilized in data collection, while content analysis was employed in data analysis. The facial herbal cosmetics products are moisturizer, whitening lotions, creams, powder, toner, make up cleansing, mask, cleansing oil, soap bar, anti-aging lotions and creams. This study revealed that most of the interviewees were female with age between 26-30 years, casual worker ,bachelor degree being the highest education and salary from 10,000 -15,000 baht (\$285-430) per month. The marketing mix (4Ps: product, price, place and promotion) were the key factors influencing Thai consumers' perception on facial herbal cosmetic products. The result found that Thai consumers were satisfied with physical appearance of products; texture, odor, penetration- characteristic and viscosity. Thai consumers trust in the safety of the Thai and imported products. The imported products have new manufacturing technologies of production compare with the Thai products but imported products are more expensive than Thai products. Thai consumers were satisfied with packaging design and pump bottle shape of imported products. Thai consumers found it was convenience to purchasing both herbal products from department store. The direct sale is popular only for Thai products. The imported products had more interesting marketing promotion than the Thai products. The marketing promotions are new product premium, promotion campaign eg. Cash discount, gift premium, fortune, tarot horoscope, makes up and massage workshop. Thai consumers were satisfied with advertisement of both herbal products; brochure, leaflet, beauty information from general magazine, fashion magazine, general book, television and radio. The economic situation, such as inflation situation, is the majority factor of purchasing decision. The average cosmetic budget per each purchase is 1,800 baht (about $\$ 50$ ) at the rate of eight purchases per year.
\end{abstract}

\section{Keywords: Perception, Thai Herbal Cosmetic Products, Imported Herbal Cosmetic Products}

\section{Introduction}

Herbal have been used as medicines for a long time. Currently, it is still utilized as important ingredients of a few consumer products including cosmetic products. There are various types of herbals, which grow naturally in Thailand. As other Asian native, Thai people realize how to use herbals for medicine and for other purposes. Herbals are used more in cosmetic products for several reasons, which are natural origin, low price and user friendly. The cosmeceutical industry has responded these expectations by flooding the market with a diversity of products claiming to be natural (Marcoux, 1999). The new "active ingredients" are derived from nature for unique marketing stories and to reduce the risk of side effect. Today, there is growing consumer demand for personal care products containing natural and/or organic ingredients. In response, there has been a dramatic growth in the sales of natural and organic personal care products in drugstores and pharmacies across the world (Antignac et al., 2011). Marketing personnel are constantly analyzing the patterns of buying behavior and purchase decision. The consumption and purchase related decision as basic purchase or consumption decision, brand purchase or consumption decision; channel purchase decision and payment purchase decision. Understanding behavior of consumers is a key to success of herbal cosmetic business organization (Jalalkamali and Nikbin, 2010). Therefore; this research aims to study the roles of herbals in cosmetic products and to study the perception of Thai consumers on the local and imported products.

The objective of this study is to examine the factors that influence Thai consumer's perception on herbal cosmetic products. To study the needs of Thai consumers on herbal cosmetic products. 


\section{Literature Review}

The cosmetics and toiletries spent almost the same amount annually on beauty products( $\$ 1454)$.In addition, almost all participants (97 percent) used at least one cosmetic product daily, averaging 7.4 products and 4.4 brands every day(Guthrie and Kim,2009). Evidently, Thai and imported herbal cosmetic products during 2006-2009 were optimistic. The growth rate is shown between 15-20 percent. During the economic slowdown, leading imported cosmetic companies have strong competition among the cosmetic supplier and distributors. All leading introduce new strategies by invest in promotional campaigns to keep theirs market share, stimulate the market but less marketing strategy of Thai herbal cosmetic products (Ministry of Finance, 2009). As manufacturers seek to create impact with performance, natural ingredients have become a key element of marketing strategies in cosmetic and toiletries, and natural's sales in the U.S. (Nancy, 2005).

The potential customers base of 18 million which women between the ages of 15 to 50 years old. Thailand's market for cosmetic products has a very strong group of potential buyer (Cosmetic Products Market in Thailand, 2009). Adolescents and teenagers have a greater concerned on theirs health (Marcoux, 1999). Herbs and plants extract has been popular in many developed countries. The organic constituents in the cosmetics categorically place them as green market. In response to customers demand for products with natural origins and anti-aging, function. The product attractiveness, cost of product acquisition, communication and point of sales promotions offered to the cosmetic customers (Rajagopal, 2007).The Silesia Organics under the name of 'Herbs for Life' produced the hand made skin care products and ointments. It gained the only $100 \%$ organic certification for beauty products from the Soil Association (UK) (Rowey \& Spiezia, 2006). Then personality of herbal cosmetic's brand influences consumer attitudes towards a brand while brand attitude describes the positive or negative feelings consumers hold toward a specific brand. Brand personality is the group of human sincerity, excitement, competent, sophistication and ruggedness.

- Sincerity conveys warmth, acceptance, honesty and caring qualities.

- Excitement portrays sociability, energy, activity and youthfulness.

- Competence describes responsibility, dependability and security.

- Sophistication describes satisfaction upper class.

- Ruggedness describes glamorous and sexy brand

The brand perception is associated with a higher level of consumer emotional response, higher levels of consumer trust and loyalty, higher consumer preference, usage, more self expression and improved product differentiation(Guthrie and Kim,2009).The purchasing behavior between the U.S. and French cosmetic markets due to psychological factors, social influences and the purchase situation(Michael and Julie,2002).The characteristics of the target market, the company's experience, expertise, and executive preference should influence the selection of a strategy for building consumer brand preference. In an increasingly frenetic marketplace, successful development of brand preference rarely results by chance. Rather, it is a deliberate choice of strategy followed by intelligent implementation and patient, persistent execution (Alreck and Settle, 1999).

Since the Korean cosmetics, market was opened to multinational cosmetics companies, fierce battles have been fought between domestic and imported cosmetics. Especially in the high-end cosmetics market, imported cosmetics armed with high product quality and marketing capability performed better than local brands (Hwan, 2004). The growing retail segment and a good scope of manufacturing are two factors that mean future growth for the Indian market. The Indian cosmetics and toiletries market has seen major changes both in terms of user perception. The increasing market size is the direct result of the changing socio-economic status of the Indian consumers, especially women. Higher paying jobs and increasing awareness of the western world and beauty trends there have served to change the tastes and customs of the middle class and higher strata of the society, with the result that a woman from such social strata now is more conscious of her appearance and is willing to spend extra cash on enhancing the further. Numbers of women, especially from the middle-class population, have more disposable income leading to a change in cosmetic and skin care products consumption (Bhattacharya, 2006). 


\section{Methodology}

The study is qualitative research using in- depth interview to collect the data and use content analysis to explained the data. This research study the perception of Thai consumers who living in Conjure province, Thailand on herbal cosmetic products(Comparative study between Thai and Imported products).The facial herbal cosmetics products are moisturizer, whitening lotions, creams, powder, toner, make up cleansing, mask, cleansing oil ,soap bar, anti-aging lotions and creams. The population of this study are Thai consumers who live in Chonburi 1,172,432 people; female $=594,554$ people, male $=577,878$ people. The sample size of Thai consumers are 25 people which non-probability sampling and currently living in Amp hoe Muang, Amphoe Banglamung in Chonburi province, Thailand. Thai consumers are both of female, male which the aged 18-48 years. In- depth interview of the open questions probing to gain personal factors of the respondent about gender, age, occupation, education, salary, opinion, attitude toward perception on purchasing decision factors: products, prices, places and promotions(4Ps). The other purchasing decision factors are the satisfaction of service after purchasing, popularity and economic situation such as inflation rate. The open questions are present below.

- Product: physical appearance of products, texture, odor of products, penetration characteristic, product safety, production technology, brand, logo, slogan, type of packaging(pump bottle, tube, pot), product size $(15 \mathrm{ml} 20 \mathrm{ml} 30 \mathrm{ml} 50 \mathrm{ml} 100 \mathrm{ml}$ ), packaging design (color, letter style).

- Price: price of product (product value).

- Place: department store, specific shop (Boots and Watsons) drug store, general shop, direct sale, internet.

- Promotion: satisfaction of beauty information from brochure, leaflet, television, AM radio, FM radio, fashion magazine, general magazine, general book, opinion in product premium, service premium (face massage, face make up), opinion in cash discount, promotion activity, necessity of beauty instructor, advertising, brand ambassador.

- Others purchasing decision factors: satisfaction of service after purchasing, popularity, and economic situation such as inflation rate.

\section{Independent Variables}

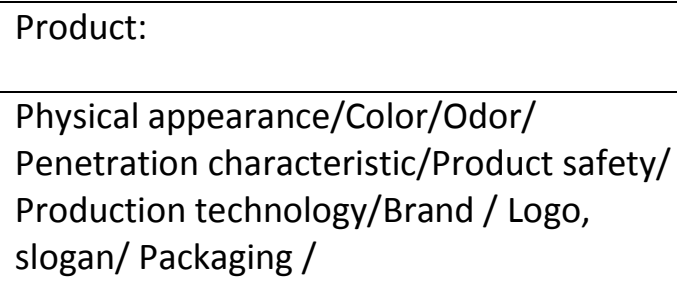

Price:

Price is purchasing decision factors.

\begin{tabular}{|l|}
\hline Place: \\
\hline $\begin{array}{l}\text { Department store/ Specific shop/Drug } \\
\text { store/General shop/Direct sale /Internet }\end{array}$ \\
\hline
\end{tabular}

\begin{tabular}{|l}
\hline Promotion: \\
\hline Brochure / Beauty instructor / Leaflet \\
Television/ FM radio/ Fashion \\
magazine/General book / Product \\
premium/Service premium / Cash \\
discount
\end{tabular}

H1

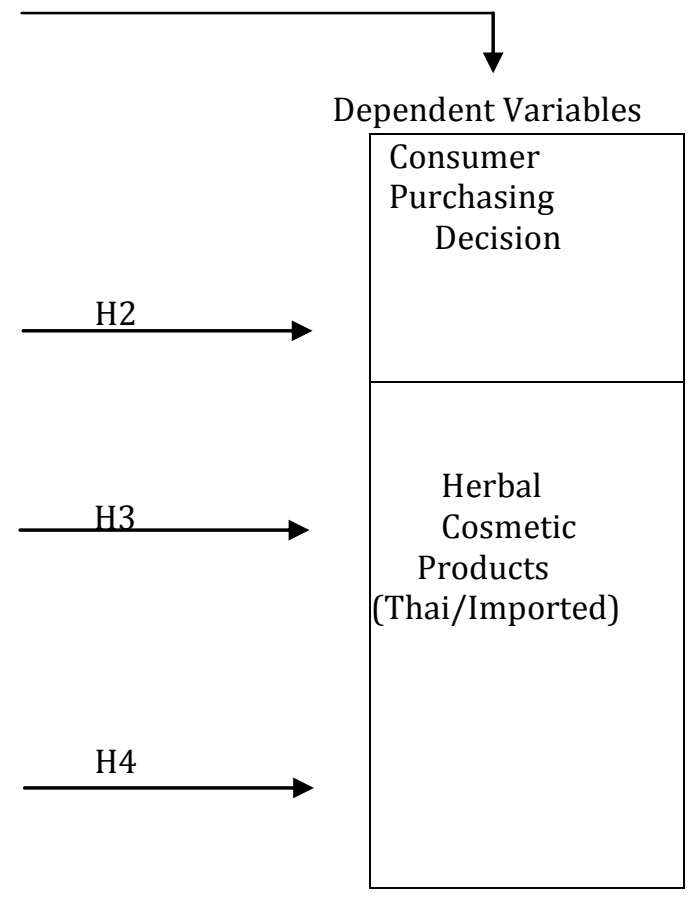




\section{Results and Discussion}

The majority of interviewees were female and the majority of age was 26-30 years.

Table 1: General personal data of interviewees.

\begin{tabular}{lcc}
\hline Personal Data & Frequency & Percentage (100\%) \\
\hline Female & 18 & 72 \\
Male & 7 & 28 \\
Age (Year) & & \\
$<20$ & 0 & 0 \\
$21-25$ & 5 & 20 \\
$26-30$ & 7 & 28 \\
$31-35$ & 6 & 24 \\
$36-40$ & 2 & 8 \\
\hline
\end{tabular}

The majority of occupation was casual worker, which the highest education was bachelor degree. The majority of salary was 10,001 to 15,000 baht $(\$ 285-430)$ per month.

Table 2: Personal data of interviewees.

\begin{tabular}{lcc}
\hline Personal Data & Frequency & Percentage (100\%) \\
\hline Highest Education & 18 & 72 \\
Bachelor degree & 7 & 28 \\
Master degree & \multicolumn{2}{c}{} \\
Job & 9 & 36 \\
Casual worker & 8 & 32 \\
Staff officer & & 3 \\
Entrepreneur & 14 & 56 \\
Salary per month (baht) & 4 & 16 \\
10,001-15,000 & 5 & 20 \\
15,001-20,000 & &
\end{tabular}

Finding of perception of Thai consumers on herbal cosmetic products are 3 categories.

Perception of Thai consumers use only Thai products were $28 \%$; women $=4$ people, men $=3$ people: Thai consumers; women 3 people and male 3 people were satisfy with physical appearance of products; texture, odor and penetration characteristics. The opinion about Thai products are safety and non-irritate. Some consumers have acne and make suggestion to improve the quality of the products. In addition, the last female felt unsatisfied with the physical appearance of products. She informed that the product is difficult to penetration to skin, but she was satisfied with the safety of the herbal products. Not all interviewees; female 4 people and male 3 people were satisfied with the pot packaging. The majority of consumers; female 4 people were satisfied with various size than imported products. The packaging have not important for 3 male interviewees. All of interviewees informed that Thai products are cheaper than imported products. All females purchase the smaller size because they want to try the products and spending less money per purchasing. The consumer found it convenience to purchase Thai products from direct sale; female 2 people and male 3 people. Some of two females purchased Thai products from department store. Majority of customers; female 3 people informed that Thai products have no product samples, lesser brochure promotion campaign. The last female and all males need beauty instructor rather than product sample and brochure. All customers; female 4 people and male 3 people informed that the economic situation such as inflation situation and social influence are purchasing decision factors.

Perception of Thai consumers who used only Imported cosmetic products were 52\%; women = 11 people , men = 3 people: All of Thai consumers ; women 11 people and male 3 people appreciated brand and production technologies of the imported products. They informed that imported products always launched new products. All of Thai consumers were satisfied with physical appearance; texture, odor and penetration characteristics. The opinion on imported products were safety and non- irritate. All of Thai consumers; female 11 people and male 3 people were satisfied with packaging. They are convenience to 
use. They were satisfied with plastic chick covering the bottle with pump packaging. They were satisfied with packaging design of imported products. All Thai consumers; female 11 people and male 3 people informed imported products are very expensive but they were satisfied with the product value. Most of Thai consumers; female 9 people and male 3 people said that it was convenience to purchase imported herbal cosmetic products from department store. Some of Thai consumers; female 2 people convenience to purchase imported products from specific shop; Boots and Watson. All female customers; female 11 people were satisfied with new launched sample products. Imported products have much promotion campaign eg. Cash discounts, gift premium, fortune, tarot horoscope, make up workshop, massage face. Thai consumers were satisfied with brochure, leaflet, beauty information from general magazine, fashion magazine, advertising in television and radio. Not all male customers were interesting in promotion. All customers; female 4 people and male 3 people informed that the economic situation such as inflation situation was their purchasing decision factor.

Perception of Thai consumers which are the majority use Imported products and the minority use Thai products were20\%; women $=3$ people, male $=1$ person: All of Thai consumers ;female 3 people and male 1 person were satisfied with the physical appearance of products; texture, odor and penetration characteristics of both Thai and imported products. The reason for their choices for both Thai and imported products are safety and non- irritation. All of Thai consumers were satisfied with packaging of the imported products, they are convenience to use. Thai consumers were satisfied the bottles with pump packaging. The majority of Thai customers; female 2 people were not satisfied packaging of Thai products. They informed that it was inconvenience for use the bottle without pump placekicking. Half of Thai consumers; female 1 person and male1 person satisfy in packaging of Thai products. All of Thai consumers; female 3 people and male 1 person informed that the imported herbal cosmetic products were very expensive, but consumers were satisfied with the product value. Thai products are cheaper than imported cosmetic products. Most of Thai consumers; female 3 people find it convenience to purchase Thai and imported products from department store. Some of consumer; male 1 person find it convenience to purchase from direct sale. Most of female; female 2 people were satisfied with a new imported products launched. It has many promotion campaigns eg. Cash discount, gift premium, fortune, tarot horoscope, makes up and massage workshop. Thai consumers were satisfied with brochure, leaflet, beauty information from general magazine, fashion magazine and advertising in television and radio. Not all male customers are interested in promotion; they were satisfied with cash discount. All of customers; female 3 people and male 1 person informed that the economic situation such as inflation situation is the purchasing decision factor.

\section{Conclusion}

For the study of the perception of 25 Thai consumers on Thai and Imported herbal cosmetic products, the result found that the most of interviewees were female gender with age between 26-30 years old, casual worker occupation, bachelor degree for their highest education and salary of 10,000 to 15,000 baht (\$250-375) per month. The marketing mix (4Ps: product, price, place and promotion) were key factors influencing Thai consumers' perception on facial herbal cosmetic products. The perception of Thai consumers on Thai products and imported products are about the physical appearance; texture, odor, penetration characteristic, viscosity of product. Thai consumers trust with the safety of the Thai and imported products. The imported products have newer technologies of production than Thai products but the imported products are more expensive than Thai production. Thai consumers were very satisfied with bottle with pump packaging of imported products but they were not satisfied with pot packaging of Thai products. Thai consumers say it is convenience to purchase the both products from department store and direct sale. Imported products have much more interesting marketing promotion than Thai products. The marketing promotions are new product premium, promotion campaigns egg. Cash discount, gift premium, fortune, tarot horoscope, make- up and massage workshop. Thai consumers satisfy in advertisement of both products; brochure, leaflet, beauty information from general magazine, fashion magazine, television and radio. The economic situation such as inflation situation is the major factor of purchasing decision. The average of cosmetic budget per purchase is 1,800 baht (about\$50) and Thai consumers purchase cosmetics in 2010 (average) are eight purchases per year. 


\section{References}

Alreck, P. \& Settle, R. (1999). Strategies for building consumer brand preference. Journal of Product Brand Management, 8,130-144.

Antignac, E., Nohynek, G., Thomas, R. \& Clouzeau, J. (2011). Safety of botanical ingredients in personal care products/cosmetics. Food and Chemical Toxicology, 49,324-341.

Bhattacharya, P. (2006). India's cosmetic ready for big leap. Global Cosmetic Industry, 174, 42-48.

Cosmetic Products Market-Thailand. (2009). Retrieved April14, 2009 from http://www.buyusa.gov/asianow/thcosmetic.html.

Guthrie, M. \& Kim, H. (2009). The relationship between consumer involvement and brand perceptions of female cosmetic consumers. Journal of Brand Management, 1, 114-133.

Hwan, S. (2004). Intergrating Technology, Marketing and Management Innovation. Research Technology Management (RTM), 47, 27-31.

Jalalkamali, M. \& Nikbin, A. (2010). The effects of motivation on purchase decision. Interdisciplinary Journal of Contemporary Research in business, 3, 234-245.

Marcoux, D. (1999). Cosmetics, skin care and appearance in Teenagers. Proceeding of coetaneous Medicine and surgery Canada, 18, 244-249.

Michael, J. \& Julie, V. (2002). Differences in purchase behavior between France and the USA: the cosmetic industry. Journal of Fashion Marketing and Management, 6, 396-407.

Ministry of finance (2009). Retrieved April14, 2009 from http://www2.mof.go.th/www2index.php.

Nancy, J. (2005). Marketers' New Edge is all-Natural. Global Industry, 173, 50-56.

Rajagopal, S. (2007). Buying decisions towards organic products: an analysis of customer value and brand drivers. International Journal of Emerging Markets, 2, 236-246.

Rowey, J. \& Spiezia, M. (2006). Spiezia Organics: SME Marketing. The Marketing Review, 6, 253-264. 